\title{
Cellular immune Response and pathology in schistosomiasis
}

\author{
AURIAULT C.*, PANCRE V.*, WOLOWCZUK I.*, ASSEMAN C.*, FERRU I.* \& VERWAERDE C.*
}

\section{Summary :}

In the present review, some aspects of the cellular response following the murine Schistosoma mansoni infection are described. Due to the peculiar route used by the schistosome to infect its definitive host, the skin appears as a critical site in which the initial events of the host/parasite relationship occur and where the immune response is initiated. Moreover, the induction and the modulation of the granuloma formation, which represent the main aspect of the pathology of this parasitic disease, is under the control of several cellular populations in which CD4 and CD8 T cells play a key role. The cytokines produced in response to the parasite, such as IL7 in the skin and IFN $\gamma$ in the liver, seem to influence the further development of immunity against Schistosoma mansoni.

KEY WORDS : schistosoma, lymphocytes, Nk cells, cytokines, epitopes granuloma, fibrosis

Résumé : ImMuntté Cellulaire ET PATHOLOGIE de la SCHISTOSOMIASE La schistosomiase, comme toutes les parasitoses, est une maladie chronique du fait de l'adaptation du parasite à son hôte. Au cours de cette infection, l'hôte développe néanmoins une réponse immune pouvant aboutir à la destruction des jeunes larves de schistosomes. De nombreux travaux réalisés chez le rat par l'équipe du Pr. Capron à I'Institut Pasteur de Lille ont pu mettre en évidence le rôle important joué par la réponse humorale dans cette immunité. Dans la présente revue, nous mettons en relief que, au cours de l'infection murine par Schistosoma mansoni, l'immunité dirigée contre les larves de schistosomes ou les œuts déposés dans les tissus et engendrant des granulomes fibreux responsables de la pathologie bilharzienne est contrôlée par différentes populations lymphoides.

Les populations cellulaires et les cytokines produites ont été étudiées à deux niveaux de l'infection : 11 dans la peau et ses ganglions drainants qui représentent les sites où est initiée la réponse immune contre les larves de schistosome (schistosomules) et où donc s'instaure en premier lieu l'interaction hôte/parasite, 2) dans le foie où la pathologie se manifeste principalement et où l'induction et la modulation de la réponse inflammatoire dirigée contre les œuts est sous le contrôle de lymphocytes T CD4 (THI et $\mathrm{TH} 2$ ) et $\mathrm{CD} 8$.

Consécutivement à l'infection, trois cytokines sont exprimées au niveau de la peau, I'IFNy, l'll4 et l'll7. Alors que les deux premières disparaissent lorsque le parasite a quitté le derme, l'IL7 continue à être produite dans la peau jusqu'à 21 jours après l'infection. Des expériences où l'infection par S. mansoni est précédée par une injection unique d'll7 au site d'infection ont clairement mis en évidence que la production cutanée de cette cytokine a une incidence profonde sur l'interaction entre le parasite et son hôte vertébré. D'une part, il apparaît que le nombre de parasites arrivant à maturité est significativement augmenté et que la migration du parasite est modifiée. D'autre part, I'ILT inhibe la production d'IFNy et, à un degré moindre, la production I'll4. La conséquence objectivable est une inversion des profils isotypiques dans le sérum des animaux infectés, des anticorps dont la production est dépendante des cytokines de type THI vers la production d'anticorps dont la production est dépendante de cytokines de type TH2. Indéniablement la peau apparaît être un site privilégié pour la survie du parasite, ce qui pourrait expliquer le maintien avec l'évolution du passage transcutané des larves de schistosome au moment de l'infection. D'autre part, l'll7 produite massivement dans la peau influence le développement ultérieur de l'immunité vis-à-vis de ce parasite en favorisant la production d'anticorps d'isotypes TH2 dont il est connu qu'ils interviennent dans la destruction des larves. Ainsi, bien qu'au cours de l'infection primaire la production d'll7 soit plutôt bénéfique pour le parasite, cette cytokine pourrait participer à la mise en place d'une immunité protectrice à la réinfection limitant ainsi la charge parasitaire, ce qui est nécessaire à la survie du couple hôte/ parasite.

Une autre série de travaux nous a permis de montrer le rôle prépondérant jové par l'IFNy dans la modulation de la fibrose hépatique au cours de la schistosomiase murine à $\mathrm{S}$. mansoni. En effet, l'injection de l'antigène vaccinant Sm28GST ou de sa séquence peptidique C-terminale 190-211 aboutit à une réduction de la synthèse de collagène et du nombre de granulomes dans le foie ainsi qu'à une survie des animaux infectés sans qu'une augmentation notable de la production d'anticorps soit observée. Le transfert passif de lymphocytes spécifiques T CD4+ mais également CD8 + reproduit l'effet protecteur de l'immunisation. Ceci suggère que les deux sous-populations lymphocytaires $T$ sont impliquées, ce qui est confirmé par des expériences de déplétion in vivo à l'aide d'anticorps monoclonaux anti-CD4 et anti-CD8. Ces cellules spécifiques de la Sm28GST ou du peptide 190-211 produisent essentiellement de I'IFNy et un peu d'll2 et pas du tout d'll4 en réponse à l'antigène Sm28GST ou le peptide 190-211. Lorsque l'immunisation est précédée par un traitement par un anticorps anti-IFNy l'effet protecteur normalement conféré par la Sm28GST est complètement annulé. Ainsi, il apparaît que c'est essentiellement par la production d'IFNy que les lymphocytes $T$ CD4+ et CD8+ spécifiques de cet antigène interviennent dans la modulation de la fibrose mais également assurent la survie des animaux infectés. La population cellulaire NK bien que reconnue comme importante productrice d'IFNy intervient de manière perceptible dans la réduction de la fibrose, mais ne semble pas agir par des mécanismes impliquant directement l'IFNY.
* URA 1854 CNRS/Institut Pasteur de Lille, 1, rue du Pr.-Calmette, 59019 Lille Cedex.
MOTS CLÉS : schistosome, lymphocyte, cellules NK, cytokine, épitope, granulome, fibrose 


\section{INTRODUCTION}

I $n$ recent years, immunological studies in parasitic models have clarified some of the components of the host parasite interface, revealing it to be the result of a permanent and delicate balance between the parasite mechanisms of survival and the host factors of immunity. Although parasite models appear in many respects as relevant systems for the investigation of immunoregulatory mechanisms, the development of safe and protective vaccines against the major parasitic diseases has hitherto failed because of the complexity of the host parasite relationships an association that allows survival of both organisms.

This is notably true in schistosomiasis, a metazoan infection that affect 200 million persons in the world and that can be studied in various animal models (Smithers \& Terry, 1965). Schistosoma mansoni infection is characterized by the presence of adult worms in the portal and mesenteric veins as the result of a complex migratory cycle initiated by cutaneous penetration of infective larvae (cercariae) living in water that transform into schistosomula into the skin of an appropriate host (Fig. 1).

S. mansoni pathology is characterized by hepatic and intestinal granuloma formation around deposited parasite eggs and tissue fibrosis (Boros, 1989). The combined use of rodent models such as the mouse and the rat and of in vitro schistosomula culture during the past decade has made possible precise analysis of the immune mechanisms in the infection. The laboratory models are currently described as "permissive " (mouse) or "semi permissive " (rat) host according to their capacity to allow the parasite to reach sexual maturation and oviposition (Cioli et al., 1977). The protective immunity is directed against the larval pre or post-lung stages and involved humoral components, notably evidenced in the rat experimental infection (Capron et al., 1981) whereas the mouse develops principally cellular dependent protective mechanisms (Sher et al., 1982; Wolowczuk et al., 1989). Much evidence has pointed to the preponderant role of $\mathrm{T}$ lymphocytes in both rat and mouse anti-schistosome immunity, notably the strict thymic dependency of the essential components of the protective mechanisms developed against the schistosomula or for the granuloma formation around the eggs (Fig. 2). Indeed, T helper lymphocytes have the ability to regulate the activity of various cell populations either by promoting B cell proliferation and differentiation, thus allowing the production of specific antibodies of the adequate protective isotypes and antibody dependent cellular toxicity (ADCC) (Capron et al., 1982) or by directly activating effector cells through their receptors for the lymphokines they produce after antigenic stimulation (James et al., 1983).

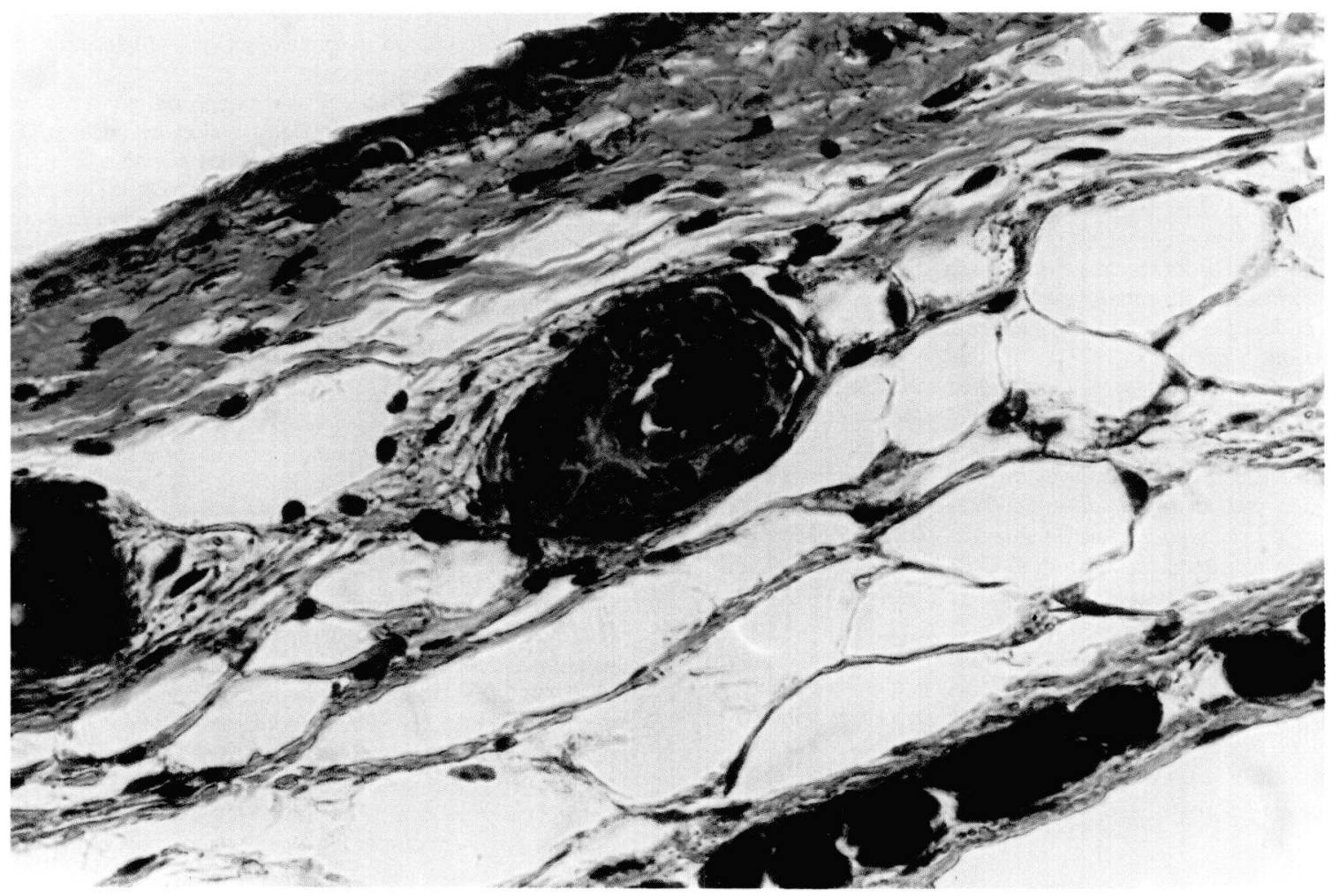

Fig. 1. - Larvae of Schistosoma mansoni in the mouse skin $30 \mathrm{~min}$ after infection. 


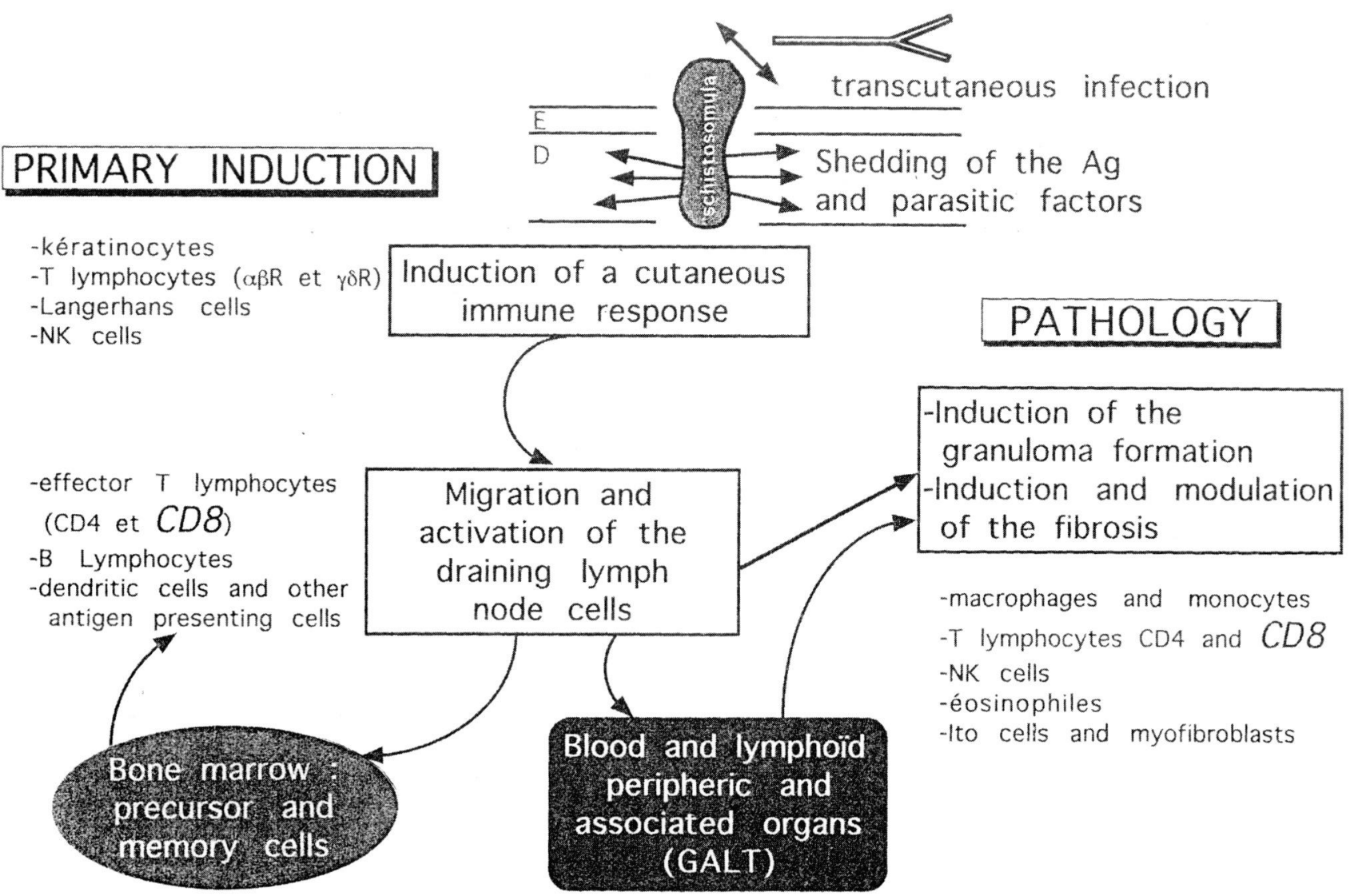

Fig. 2. - Induction of the cellular response in schistosomiasis.

In the present article we will summarize some aspects of the cellular response consecutive to the cercariae penetration in the skin and the consequence in the host/parasite relationship. Moreover we will focus the role played by $\mathrm{T}$ lymphocyte sub populations (CD4 and more particularly CD8) elicited by Sm28GST a vaccinating molecule of Schistosoma mansoni. Finally, the presentation of the major $\mathrm{T}$ cell epitopes and the parameters of immunity they induced will be presented in the last chapter.

\section{THE SKIN AND THE INITIATION OF THE IMMUNE RESPONSE}

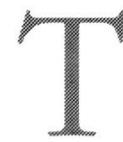
he very peculiar infection route used by the parasite S. mansoni, i.e. through the intact skin of its definitive host, prompted us to question whether penetration of cercariae and migration of larvae through the skin intervene in the host/parasite relationship. Indeed skin is an important part of the immune system and the site of complex humoral and cellular responses. Thus the schistosome infection site can be regarded as a self-supporting immunological organ comprised of keratinocytes, epidermal Lange- rhans cells and skin homing $\mathrm{T}$ cells supporting the idea that epidermis could play a key role in the initiation of the immune response to this parasite.

To answer this question a series of experiments were carried out to compare the cytokine production in skin from mice infected transcutaneously or intravenously in comparison with non infected animals. The cytokines studies were IL1, IL2, IL4, IL5, IL6, IL7, IL10, IFNy and $\alpha \mathrm{TNF}$ and their profiles were monitored for 90 days infection (Wolowczuk et al., submitted).

It was observed that certain cytokines such as IL1 and $\alpha \mathrm{TNF}$ were present only in the skin of infected mice either after transcutaneous or intravenous infection. In contrast, IL2, IL5 and IL10 were detected in none of the samples at any time post infection. Interestingly, IL4, IL7 and IFN $\gamma$ were found exclusively in the skin transcutaneously infected mice. The maximal detection of IL 4 and IFN $\gamma$ in skin was observed 5 days following parasite migration coinciding with larvae leaving the skin for the lung. The striking observation of a long lasting production of IL7, up to 21 days of infection in the skin, led us to evaluate the role of this cytokine in murine infection.

A single intradermal administration $(0.3 \mu \mathrm{g})$ of recombinant IL7 was made at the site of injection prior to parasite deposition on the skin. Amazingly this study 
demonstrated that in vivo IL7 treatment aggravated the clinical course of murine schistosomiasis in $\mathrm{C} 57 \mathrm{bl} 6$ mice, paralleled by an increased adult worm burden and a more dramatic fibrosis in the liver. Regarding this parasite-host interaction in the skin, this raised fascinating questions. Indeed, this suggested that the cutaneous route of infection favoured the parasite during the initial phases of the infection and that local production of IL7 by dermal cells (presumably keratinocytes) has a positive effect on the survival of the infected larvae. Moreover the presence of IL7 in skin of infected mice would directly act on the migration of the parasite within the infected host. Indeed the results of perfusion of isolated livers at day 15 post infection showed that there were less larvae in livers of IL7 treated infected mice. Since the migration route of the parasite has been shown to be involved in the development of protective immunity, we are now investigating in more detail the mechanisms controlled by IL7, notably the regulation of adhesion molecules in the skin or in the draining lymph nodes (Fig. 3). In the mouse, the division of CD4+ $\mathrm{T}$ cells clones into IL2 and IFN $\gamma$ producing TH1 subset and IL4, IL5 and IL10 producing TH2 subset is now well established (Mossmann et al., 1986). The other consequence of the presence of IL7 in the skin was the dramatic decrease of IFN $\gamma$ and to a lesser extend of IL 4 in the skin, the draining lymph nodes and the sera of infected mice. In the well documented model of percutaneous vaccination with irradiated cercariae, it has clearly been demonstrated that protection against challenge infection is mediated by IFN $\gamma$ producing $\mathrm{CD} 4+$ cells (Mountford et al., 1992). As a first event the strong reduction of IFN $\gamma$ would lead to a less effective cell mediated parasite killing in the lungs leading to a higher worm burden consecutively in the liver. The second consequence could be the emergence of TH2 type cells occurring during S. mansoni infection, and characteristic of the helminth infections, due to the modification of the equilibrium between IFN $\gamma$ and the other cytokines. The result was the modification in TH1-TH2 associated isotype profiles, respectively IgG2a and IgG1, of egg antigen specific IgG. The IL7 dependent decrease of IFN $\gamma$ being associated to a similar decrease of IL12 in skin draining lymph nodes which both play a major role in promoting TH1 differentiation, could favour the development of TH2 cells and consecutively of the antibody isotypes under their control.

Thus, the skin appeared as a crucial site in which the initial events of the host/parasite interaction occur. Undoubtely, skin appears as a site necessary for the parasite survival (at least at the first infection) but also as an organ of immune sensitization following infection with $S$. mansoni. Even if might not itself be the

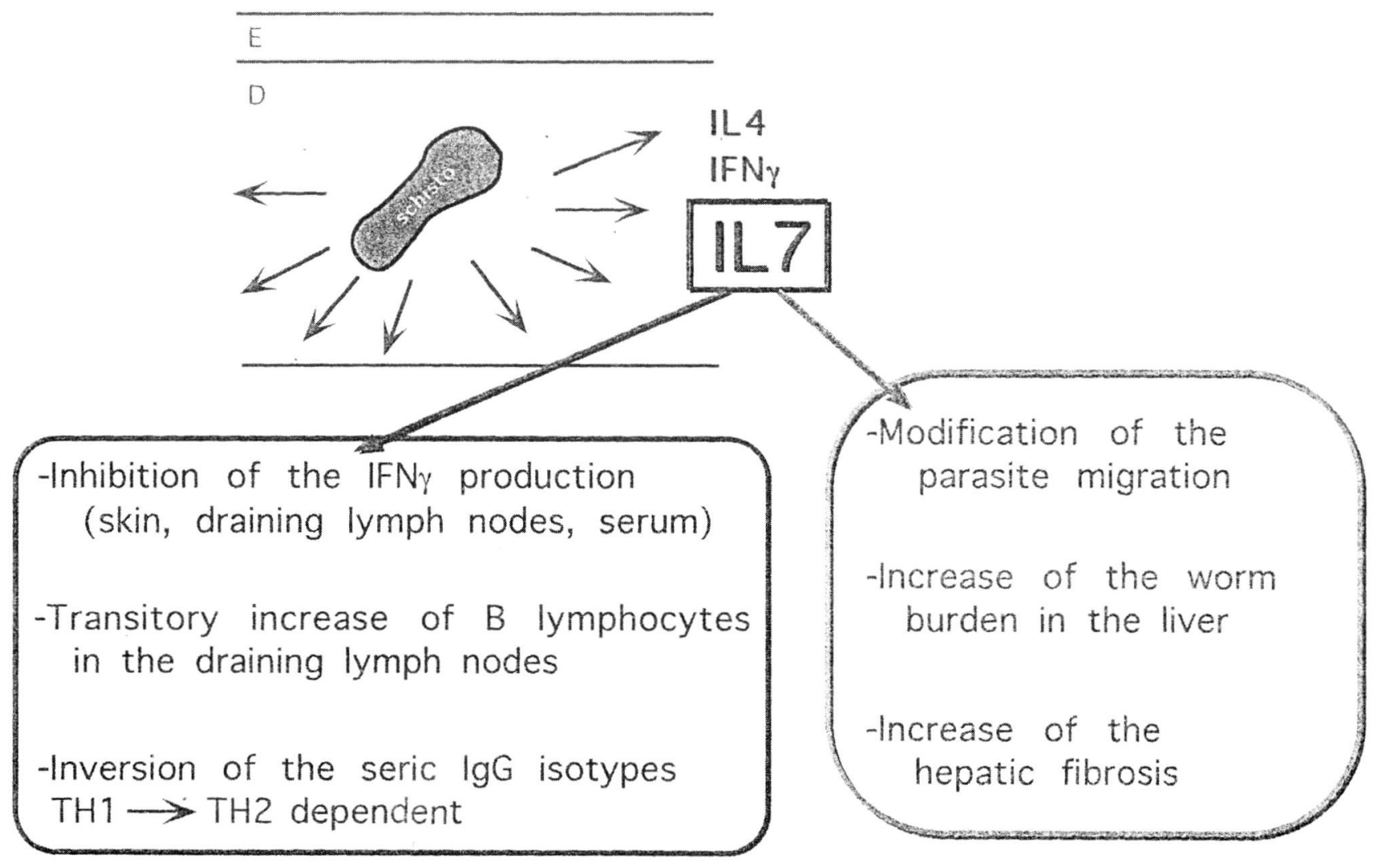

Fig. 3. - Induction of the cellular response in the skin toward schistosome in C57 bl6 mice. 
site of complete initiation of the immune response to this parasite, which occur in the skin lymph nodes, these results showed that events in the skin could influence the further development of immunity against S. mansoni.

\section{INDUCTION AND REGULATION}

\section{INDUCTION AND REGULATION OF THE GRANULOMA FORMATION BY T LYMPHOCYTES IN MURINE SCHISTOSOMIASIS}

I $\mathrm{n}$ mice the pathology of schistosomiasis is associated with the continual daily production of viable eggs by the intravascular worms. Many of the eggs do not reach the external environment and cause an inflammatory response when trapped in liver sinusoids leading to predominantly cell-mediated granuloma formation and ultimately to hepatic fibrosis (Philips et al., 1986). This fibrosis involves the excessive deposition of newly synthesized connective tissue matrix with collagen being the major component (Wyler et al., 1987). It is now admitted that this pathophysiologic scenario is carefully regulated by multiple subpopulations of distinct subsets of T lymphocytes. Egg-induced granuloma formation in the liver has been characterized as a CD4+ cell mediated delayed-type hypersensitivity response, which is maximal by 8 weeks after infection (Mathew et al., 1986, 1990). Granuloma are then down regulated by CD8+ lymphocytes (Chensue et al., 1981; Fidel \& Boros, 1990) so that by 16 to 20 weeks after infection newly formed granuloma have decreased in size. The presence of CD8+ cells was observed in both early and chronic granulomas with an increased ratio of CD8+ cells in chronic granulomas (Ragheb \& Boros, 1989). The secretion of TH2-related cytokines which follows egg deposition, is vigorous 8 weeks after infection whereas TH1-related responses which could limit worm survival are suppressed (Pearce et al., 1991). IL10 production, which occur simultaneously with the reduction in the IFN $\gamma$ response, may be responsible for the observed suppression of TH1 cell cytokine synthesis. TGF $\beta$, a cytokine with potent immunosuppressive activity is also produced during the infection and could contribute to this regulatory phenomenon (Czaja et al., 1989). Later in infection, TH2 responses are themselves down regulated (Grzych J.-M. et al., 1993). Previous studies have implicated CD8+ cells in this suppression (Colley, 1981) and it is possible that IFN $\gamma$, already shown to strongly influence TH1/TH2 ratio is responsible for this decrease in IL4 and IL5 production (Fong \& Mossmann, 1990; Gajewski \& Fitch, 1988). This indicate that expression of both protective immunity and pathologic changes is regulated by a complex network of coordinated responses leading to the concept of a cross regulatory circuit.

\section{MODULATION}

MOdulation OF THE GRANUlOMA FORMATION BY SM28GST SPECIFIC T CELLS

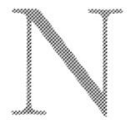

umerous efforts over the last decade have focused in the elaboration of a reliable vaccine able to protect humans against natural infection by $S$. mansoni. Although attenuated larvae can induce a significant level of immunity in various experimental models (Taylor \& Bickle, 1986) it is commonly agreed that a non living defined vaccine would be easier to produce on a large scale by recombinant DNA technology, as well as being ethically more acceptable in human populations (Murray, 1989). One of the promising candidate, the $28 \mathrm{kDa} S$. mansoni glutathionS-transferase (Sm28GST) (Taylor et al., 1988) molecule has been the focus of several experimental studies allowing a better understanding of its immunogenicity and its biological function. The corresponding recombinant Sm28GST molecule induces a significant degree of protection after being inoculated into permissive host as hamster, mice and baboons or a semi-permissive host such as the rat (Balloul et al., 1987; Wolowczuk et al., 1989) and also strongly reduces the egg induced-related pathologic changes (Boulanger et al., 1991). Whereas protection against challenge infection is in part antibody (IgE and $\operatorname{IgA}$ ) mediated (Dunne et al., 1992) the role of T lymphocyte subpopulations in the modulation of the liver pathology deserved to be evaluated in the immunization procedures.

In a series of experiments we observed a marked reduction in the number of granuloma and of fibrosis in the liver of Schistosoma mansoni-infected mice after immunization with a single dose of recombinant Sm28GST (Pancré et al., 1994). Moreover immunized mice seemed durably protected since they survived more than 23 weeks after the death of control animals while no relationship was noted between antiSm28GST IgG and IgA antibody titers and the level of protection obtained by this immunization protocol. This supported the hypothesis of a role of Sm28GST specific $\mathrm{T}$ cells in the reduction of the hepatic lesions. Effectively, the adoptive transfer of Sm28GST specific total $\mathrm{T}$ cell population, recovered 28 days after immunization, reproduced this protective effect obtained. Protection, although less marked was also obtained after passive transfer of Sm28GST specific T cell subpopulation, but no significant difference in the level of protection between mice given $\mathrm{CD} 4+\mathrm{T}$ cells and mice given CD8+ T cells was observed, suggesting that both subpopulations were involved in the protection 
conferred by the total $\mathrm{T}$ cell population. In addition in vivo $\mathrm{T}$ cell depletion experiments showed that antiCD4 and anti-CD8 treatment of mice led to an important decrease in the Sm28GST mediated reduction of the liver pathology. Our results suggest that the two $\mathrm{T}$ cell subpopulations have a role in the expression of the protection against hepatic damage. The tendency of recombinant Sm28GST for preferential elicitation of IFN $\gamma$ production by splenocytes indicated a probable role for this antigen in directing the type of CD4TH1 but also CD8 $\mathrm{T}$ cell responses observed in early stage of infection (Fig. 4).

IFN $\gamma$ is a potent inhibitor of collagen synthesis both in vitro and in vivo and one can envisage a role for this cytokine, secreted by Sm28GST specific CD $4+$ and CD8+ cells in the observed reduction of the hepatic damage. To evaluate this hypothesis, treatment of immunized mice with an anti-IFN $\gamma$ antibody was car- ried out. This treatment suppressed the Sm28GST induced protective effect and led to the rapid death of anti-IFN $\gamma$ treated animals. Thus the neutralization of IFN $\gamma$ during challenge response may shift the TH balance toward domination by the TH2 subset and promote parasite survival. Moreover, the use of IFNy under our experimental conditions of infection resulted in a marked decrease in the hepatic damage and in survival of the treated mice. This observation is in accord with the results of Cazja et al. (1989) who demonstrated that in murine schistosomiasis there was a profound inhibition of collagen deposition accompanied by reductions in mRNA content for type I and III procollagen after treatment by IFN $\gamma$. The protective role of Sm28GST specific CD8+ T cells in the murine infection prompt us to evaluate the cytotoxic (CTL) potentialities of these cells. We have shown that Sm28GST was able to stimulate an antigen-specific,
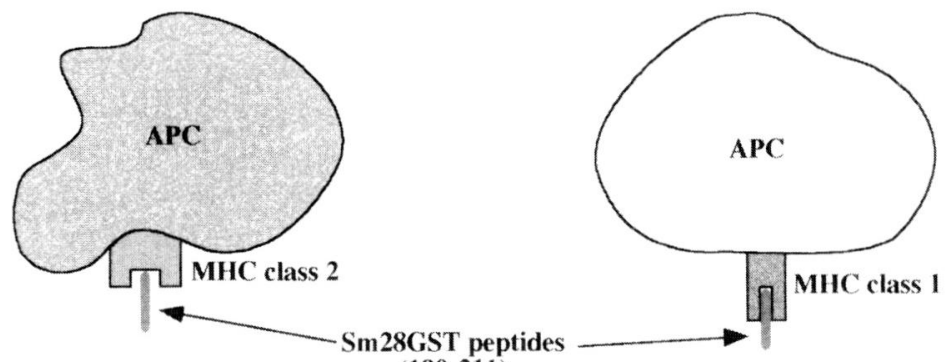

$(190-211)$
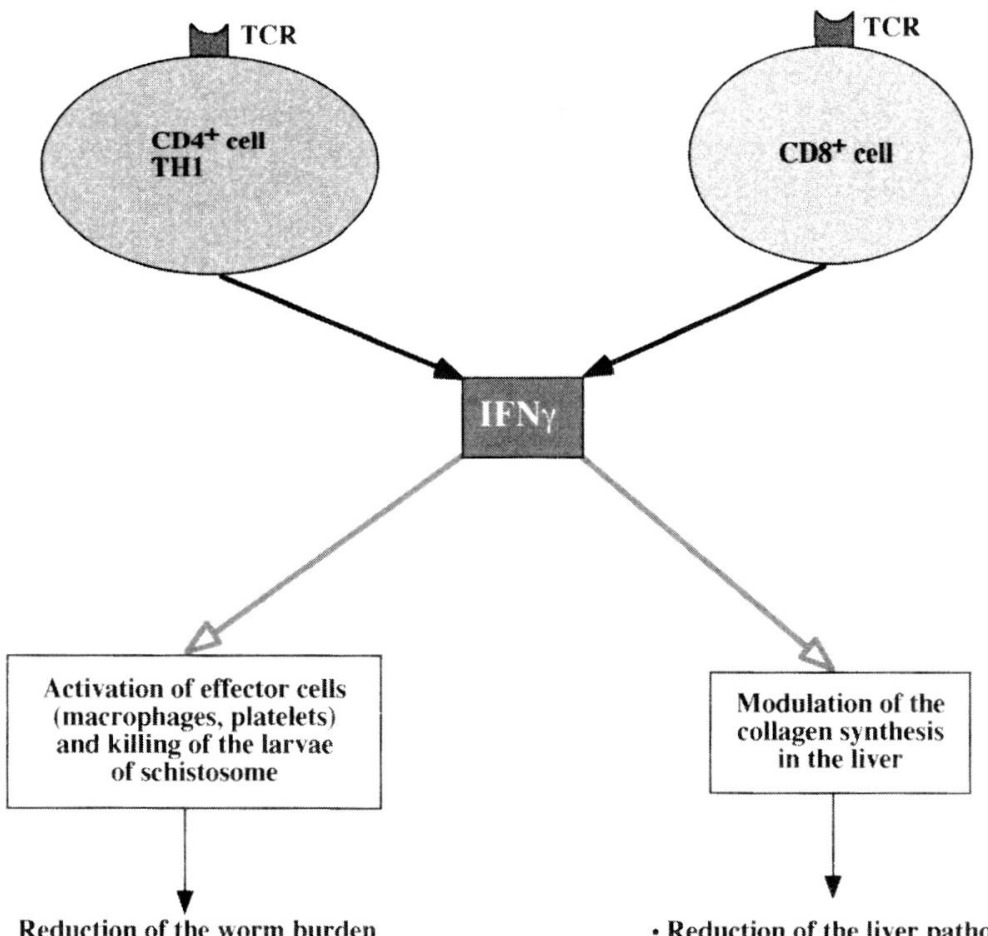

IFNY

Reduction of the worm burden

- Limitation of the transmission?

Fig. 4. - Pivotal role of $\gamma$-IFN in the protection conferred by Sm28GST specific T lymphocytes in murine schistosomiasis. 
cytotoxic $\mathrm{T}$ cell response against Sm28GST-pulsed P815 target cells in normal mice. Moreover, effector cells induced in vivo were classical class 1 MHC restricted CD8+ lymphocytes (Pancré et al., submitted). We evidenced no spontaneous CTL activity against Sm28GST-pulsed target cells during the course of the infection by $S$. mansoni although Sm28GST is expressed at different developmental stages of the parasite. But we observed that immunization with Sm28GST is sufficient to elicit a significant level of CTL response for 6 weeks in infected mice. This experimental approach should allow to appreciate the precise role of CD8+ T cells expressing cytotoxic functions in a parasitic disease implicating a non intracellular infective agent.

\section{NK CELLS AND PATHOLOGY IN SCHISTOSOMIASIS}

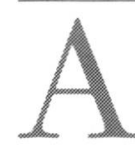

$s$ evoked above numerous studies evidence that IFN $\gamma$ plays important immunoregulatory functions in schistosomiasis. Natural killer cells representing a major source of IFN $\gamma$ (Kobayashi et al., 1989) the regulatory functions of these cells in schistosomiasis have previously been studied in the lung using an artificial model of synchronized granuloma elicited by intravenous egg injections. This work showed that the depletion of asialo-GM1+ cells, a surface marker expressed by NK cells (but also by other populations notably macrophages) (Suttles et al., 1986) leads to an augmentation of primary granuloma size and TH2 cytokine mRNA expression while decreasing TH1 cytokine mRNA level. In our laboratory we investigated the effect of in vivo NK1-1+ cell depletion both in the development of conventional granuloma in the liver and in the immune response (Asseman et al., submitted). The depletion was started before infection and maintained throughout the chronic stage using the monoclonal antibody Pk136 directed towards NK-1.1 a surface marker of the murine NK cells (Glimcher et al., 1977) also expressed on a rare CD $4+\mathrm{T}$ cell population (Yoshimoto et al., 1995). The study was focused on possible modifications in the liver pathology and of immune promoters in regard to the capacity of NK cells to produce IFN $\gamma$ but also as a source of IL4 from the CD4+ NK1.1 T cell population. It was shown that NK1.1+ cell depletion caused perceptible modifications in the liver, increasing collagen content and leading to the abolition of IL12 p40 and IL7 mRNA expression. Hepatic mRNA expression of other cytokines-like IFN $\gamma$, TNF $\alpha$ and IL 4 as well as humoral and cytokine responses in sera of infected animals were not significantly different between control monoclonal antibody and anti-NK1.1 treated animals. We also tested a model of immunization using Sm28GST known to induce IFN $\gamma$ mediated protection associated with diminution of hepatic fibrosis. In this situation treatment with anti-NK1 monoclonal antibody provoked a marked augmentation of hepatic fibrosis in immunized mice although no alteration of IFN $\gamma$ production was observed.

Taken together these results demonstrate that the absence of NK1.1 cells might induce alterations of regulatory mechanisms during a chronic infection in immunocompetent mice, that did not otherwize display any appreciable variations of cytokine production. Nevertheless the role of NK cells probably not only occur through the production of IFN $\gamma$ since no modification of IFN $\gamma$ production of this cytokine was observed after treatment with anti NK1.1 monoclonal antibody. This suggests that NK1.1 cells might locally participate in regulatory mechanisms involved in the liver pathology in schistosomiasis.

\section{THE MOLECULAR TARGETS OF THE EFFECTOR T LYMPHOCYTES}

STRATEGY OF VACCINATION WITH SYNTHETIC PEPTIDE CONSTRUCTIONS

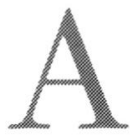

ntigens are presented to $\mathrm{T}$ lymphocytes in the form of peptides associated with either class I or class II molecules (Berzofsky, 1985; Sette et al., 1987; Bjorkman et al., 1987; Brown et al., 1993). So the possibility of using synthetic peptides as vaccine against parasitic disease has evoked considerable interest during the last decade. At this stage of the study it seemed necessary to determine which part of the Sm28GST molecule was the target of the response leading to the reduction of the lesions observed in the liver of infected mice. Previous peptide mapping of this molecule has identified a number of major epitopes. The 115-131 peptide contained both $\mathrm{T}$ and $\mathrm{B}$ cell recognition sites when tested on a variety of animals including rat, mice and monkey (Auriault et al., 1991). Moreover, immunization with the octomeric construction (MAP-8) of the 115-131 fragment has been shown to confer significant protection to rats against a challenge infection in term of a reduction of worm burden (Wolowczuk et al., 1991). A study using PBL from Kenyan patients infected by Schistosoma mansoni has identified the 190-211 peptide as one of the main T cell epitopes (Wolowczuk et al., submitted). The 2443 peptide has been described as being predominantly involved in $\mathrm{T}$ cell response in mice. In addition immunization of mice with the 10-43 and 190-211 peptides induced a reduction in the number of intestinal and hepatic eggs and their ability to hatch (Xu et al., 1993). Other studies suggested that among the peptides derived from the Sm28GST antigen, the 190-211 peptide representing the carboxylic end of the mole- 
cule, exhibited a real vaccinating potential, since this sequence was able to reproduce the protective effect obtained with the whole molecule (Xu et al., 1993; Pancré et al., 1994). In particular at day 42 of infection, the level of collagen in the liver, associated to a reduction of splenomegaly, of 190-211 peptide immunized mice was close to that observed in normal mice; moreover immunized mice seemed durably protected since they survived more than one month after the death of control animals. The protection that we observed despite the absence of antibody production strongly suggested a participation of cell dependent mechanisms in the immunity conferred as was the case when Sm28GST was used as immunogen. This was confirmed after passive transfer of 190-211 peptide specific $\mathrm{T}$ cell enriched spleen cells which reproduced the protective effect obtained after administration of the 190-211 peptide (Pancré et al., 19, 1994). Preliminary results suggests that the protection conferred was essentially due to CD8+ T cells and that IFN $\gamma$ plays a key role in the process. Indeed spleen cells from 190211 peptide immunized mice produced essentially IFN $\gamma$ after stimulation with Sm28GST. A weak production of IL2 but no IL 4 was recovered from the same supernatants. The protocol of i.p. immunization was initially used to induce CD8+ CTL. Thus one possibility could be that 190-211 CD8+ CTL have been induced acting either directly or through the secretion of cytokines such as IFN $\gamma$. This hypothesis is presently tested using Knock-out mice for MHC class II $\beta$ chain, or $\beta 2$-microglobulin.

In order to increase the immunogenicity of the 190211 peptide we decided to evaluate the protective properties of the 190-211 peptide modified by a lipidic construct. Indeed it is known that the modification of short synthetic peptides mixed in lipophilic adjuvant or linked to P3CSS (Schmild et al., 1991) are best for priming anti-virus CTL (Gao et al., 1991; Hart et al., 1991). The 190-211 lipopeptide was compared to the initial peptide for its capacity to reduce hepatic lesions under the same experimental conditions. The protective effect of the 190-211 peptide was increased essentially since it induced a more stable and durable reduction of the $S$. mansoni induced hepatic pathology and a long term survival of infected animals.

To evaluate the qualitative aspects of the immune response elicited by the 190-211 peptide used either free or synthesized as a lipopeptide, the two peptidic forms were injected in three different syngeneic mouse strains: Balbc $\left(\mathrm{H}-2^{\mathrm{d}}\right), \mathrm{CBA} / \mathrm{N}\left(\mathrm{H}-2^{\mathrm{k}}\right)$ and $\mathrm{C} 57 \mathrm{Bl} / 6(\mathrm{H}-$ $2^{\mathrm{b}}$ ) using different routes of immunization (subcutaneous, oral and intraperitoneal). The analysis of $\mathrm{T}$ cell responses was carried out by proliferation assay and detection of mRNA specific for different cytokines, whereas $\mathrm{B}$ cell response was evaluated by analysis of the isotypic antibody response (Ferru et al., submitted). Taken together the data obtained showed that immunization with the free peptide mainly leads to a TH1 profile, while lipopeptide immunization leads to either TH2, THO and TH1 profiles depending on the mouse strains and the route of administration. Neither the T cell proliferative response nor the antibody production were significantly modified. Thus, the addition of a fatty acid to the 190-211 peptide effectively increased the global immunogenicity of this peptide but essentially by enlarging the spectrum of cytokines produced by the $\mathrm{T}$ cells rather than by increasing the proliferative response or the antibody production. These results provide encouraging information for the possible use of synthetic peptides in the imunoprophylaxis of schistosomiasis.

\section{CONCLUDING REMARKS}

T his review has pointed out the important role played by helper cells in $S$. mansoni murine infection. This experimental model have demonstrated that TH1 and TH2 subset of T cells are probably involved in protective immunity. Ongoing studies are directed towards defining the phenotype of the $\mathrm{T}$ cells that govern resistance or pathogenesis in the human infection. Studies performed in subjects living in areas endemic for Schistosoma mansoni (Rihet et al., 1991; Dunne et al., 1992) and Schistosoma haematobium (Hogan et al., 1991) showed that in human resistance to reinfection is associated with high levels of parasite specific $\operatorname{IgE}$ and that immunity increased with age concomitantly with parasite-specific IgE mediated immunity and by an antagonism between parasite specific IgE and IgG4 (Demeure et al., 1993). Other studies carried out in Kenya suggested that IL5 might also be associated with protective immunity in subject older than 14 years (Roberts et al., 1993). A recent study demonstrate that parasite specific $\mathrm{T}$ cell clones isolated from adult resistant to $S$. mansoni belong to the TH0 subset and produced more IL 4 that IFN $\gamma$ whereas clones of a sensitized adult from a nonendemic area while being also TH0 produced more IFN $\gamma$ than IL4. This support previous conclusions on the role of TH2 dependent antibody isotypes such as IgE, but also suggests that IFN $\gamma$ is required for full protection in human (Coussinier-Paris and Dessein, 1995). Thus, human resistance to $S$. mansoni infection seems associated with Schistosoma specific T helper cells producing both IL 4 and IFN $\gamma$. Research on the basic immunology of schistosomiasis allows a clearer understanding of the mechanisms of resistance and also provides original and important insight into the immune response and its regulation in a complex pathology. 


\section{REFERENCES}

Asseman C., Pancré V., Quatannens B. \& Auriault C. Effect of natural killer cell depletion on immunity and pathology in murine schistosomiasis (submitted).

Auriault C., Wolowczuk I., Gras-Masse H., Marguerite M., Bollanger D., Capron A. \& Tartar A. Epitopic characterization and vaccinal potential of peptides derived form a major antigen of Schistosoma mansoni (SSm28GST). Peptides Research, 1991, 4, 6-11.

Balloul J.M., Grzych J.M, Pierce R.J. \& Capron A. A purified 28,000 dalton protein from Schistosoma mansoni adult worms protects rats and mice against experimental schistosomiasis. Journal of Immunology, 1987, 138, 3488-3453.

BERZOFSKY J. Intrinsic and extrinsic factors in protein antigenic structure. Science, 1985, 229, 932.

Bjorkman P., Saper M., Samraoui B., Bennett W., StgroMinger J. \& Wiley D. Structure of the human class I histocompatibility antigen HLA-A2. Nature, 1987, 329, 506.

Boros D.L. Immunopathology of Schistosoma mansoni infection. Clinical Microbiology Review, 1989, 2, 250-269.

Boulanger D., Reid G.D.F., Sturrock R.F., Wolowczuk I., Balloul J.M., Grezel D., Pierce R.J., Otieno M.F., Guerret S., Grimaud J.A., Butterworth A.E. \& Capron A. Immunization of mice and baboons with the recombinant Sm28GST affects both worm viability and fecundity after experimental infection with Schistosoma mansoni. Parasite Immunology, 1991, 13, 473-490.

Brown J., Jardetzky T., Gorga J., Stern L., Urban R., Strominger J. \& Wiley D. Three dimensional structure of the human class II histocompatibility antigen HLA-DR1. Nature, 1993, 364, 33.

Capron A., Dessaint J.P, Capron M., Joseph M. \& Torpier G. Effector mechanisms of imunity to schistosomes and their regulation. Immunological Review, 1982, 61, 41-66.

Capron M., Bazin H., Joseph M. \& Capron A. Evidence for IgE-dependent cytotoxicity by rat eosinophils. Journal of Immunology, 1981, 126, 1764-1770.

Cazja M.J., Weiner F.R., Takahashi S., Gambrone M.A., Van der Meide P., Schellekens H.,. Biempica L. \& Zern M.A. $\gamma$-Interferon treatment inhibits collagen deposition in murine schistosomiasis. Hepatology, 1989, 5, 795-800.

Chensue S.W., Wellhausen S.R. \& Boros D.L. Modulation of granulomatous hypersensitivity. II. Participation of Ly $1^{+}$ and Ly $2^{+} \mathrm{T}$ lymphocytes in the suppression of granuloma formation and lymphokine production in Schistosoma mansoni-infected mice. Journal of Immunology, 1981, $127,3630-3635$.

Cioli D., Knopt P.M. \& Senft A.W. Study of Schistosoma mansoni transferred into permissive and non-permissive hosts. International Journal of Parasitology, 1977, 7, 293-297.

Colley D.J. T lymphocytes that contribute to the immunoregulation of granuloma formation in chronic murine schistosomiasis. Journal of Immunology, 1989, 126, 14651468 .

Demeure C.E., Rihet P., Abel L., Ouarrara M., Bourgois A. \& Dessine A.J. Journal of Infection Diseases, 1993, 168, 1000.
Dunne D.W., Butterworth A.E., Fulford J.C., Kariuki H.C., Langley J.G., Ouma J.H., Capron A., Pierce R.J. \& SturROCK R.F. Immunity after treatment of human schistosomiasis: association between IgE antibodies to adult worm antigens and resistance to reinfection. European Journal of Immunology, 1992, 22, 1483-1494.

Ferru I., Roluin C., Estaquier J., Delacre M., Tartar A., GrasMasse H. \& Auriault C. Induction of the immune response to a lipopeptidic construction or the corresponding free form depends on the MHC restriction and the mode of immunization (submitted).

Fidel P.L. \& Boros D.L. Regulation of granulomatous inflammation in murine schistosomiasis. IV. Antigen-induced suppressor T cells down-regulate proliferation and IL-2 production. Journal of Immunology, 1990, 145, 12571264.

Fong T.A.T. \& Mossmann T.R. Alloreactive murine CD8+ T cell clones secrete the Th1 pattern of cytokines. Journal of Immunology, 1990, 144, 1744-1752.

GAJEWSKI T.F. \& FiTCH F.W. IFN- $\gamma$ inhibits the proliferation of Th2 but not Th1 murine helper $\mathrm{T}$ lymphocyte clones. Journal of Immunology, 1988, 140, 4245-4252.

Gao X.M., Zheng B., Liew F.Y., Brett S. \& Tite J. Priming of influenza virus-specific cytotoxic T lymphocytes in vivo by short synthetic peptides. Journal of Immunology, 1991, $147,3268-3273$.

Glimcher L., Shen F.W. \& Cantor H. Identification of a cellsurface antigen selectively expressed on the natural killer cell. Journal of Experimental Medicine, 1977, 145, 1-9.

Grzych J.M., Grezel D., XU C.B., Neyrinck J.L., Capron M., Ouma J.H., Butterworth A.E. \& Capron A. IgA antibodies to a protective antigen in human schistosomiasis mansoni. Journal of Immunology, 1993, 150, 527-535.

Hagan P., Blumenthal U.J., Dunne D., Simpson A.J.G. \& WilKINS H.A. Human IgE, IgG4 and resistance to reinfection with Schistosoma haematobium. Nature, 1991, 349, 243.

Hart, M.K., Weinhold K.J., Scearce R.M., Washburn E.M., Clark C.A., Palker T.J. \& Haynes B.F. Priming of antihuman carrier-free immunodeficiency virus (HIV) $\mathrm{CD}^{+}$ cytotoxic T cells in vivo by HIV synthetic peptides. Proceedings of the National Academy of Sciences of the U.S.A., 1991, 88, 9448-9452.

James S.L., Lazdin J.K., Hieny S. \& Natovitz. Macrophages as effector cells of protective immunity in murine schistosomiasis. VI. T cell-dependent mediated activation of macrophage in response to Schistotoma mansoni antigens. Journal of Immunology, 1983, 131, 1481-1488.

Kobayashi M.L., Fitz L., Ryan M., Hewick R.M., Clark S.C., Chan S., loudon R., Ssherman F., Perussia B. \& TrinCHIERI G. Identification and purification of natural killer cell stimulatory factor (NKSF), a cytokine with multiple biological effects on human lymphocytes. Journal of Experimental Medicine, 1989, 170, 827-845.

MATHEw R.C. \& Boros D.L. Anti-L3T4 antibody treatment suppresses hepatic granuloma formation and abrogates antigen-induced interleukin-2 production in Schistosoma mansoni infection. Infection and Immunity, 1986, 54 , 820-826. 
Mathew R.C., Ragheb S. \& Boros D.L. Recombinant IL-2 therapy reverses diminished granulomatous responsiveness in anti-L3T4-treated, Schistosoma mansoni-infected mice. Journal of Immunology, 1990, 144, 4356-4361.

Mosmann T.R., Cherwinski H., Bond M.W., Giedlin M.A. \& CofFman R.L. Two types of murine helper T celle clones. I. Definition according to profiles of lymphokine activities and secreted proteins. Journal of Immunology, 1986, $136,2348-2357$.

Mountford A.P., Coulson P.S., Pemberton R.M., Smythies L.E. \& WILSON R.A. The generation of interferon-gamma-producing $\mathrm{T}$ lymphocytes in skin-draining lymph nodes, and their recruitment of the lungs, is associated with protective immunity to Schistosoma mansoni. Immunology, 1992, $75,250-256$

Murray P.K. Molecular vaccines against animal parasites. Vaccine, 1989, 7, 291-299.

Pancré V., Gras-Masse H., Delanoye A., Herno J., Capron A. \& Auriault C. Induction of cytotoxic T cell (CTL) activity by the protective antigen of Schistosoma mansoni Sm28GST or its derived C-terminal peptide (submitted).

Pancré V., Wolowczuk I., Bossus M., Gras-Masse H., Guerret S., Delanoye A., Capron A. \& Auriault C. Evaluation of the effect of Sm28GST-derived peptides in murine hepatosplenic schistosomiasis: interest of the lipopeptidic form of the C-terminal peptide. Molecular Immunology, 1994, 31, 1247-1256.

Pancré V., Wolowczuk I., Guerret S. \& Copin M.C. Protective effect of rSm28GST-specific T cells in schistosomiasis : role of gamma interferon. Infection and Immunity, 1994, 62, 3723-3730.

Pearce E.J., Caspaf P., Grzych J.M., Lewis F.A. \& Sher A. Down-regulation of Th1 cytokine production accompanies induction of Th2 responses by a parasitic helminth, Schistosoma mansoni. Journal of Experimental Medicine, 1991, 173, 159-166.

Phillips D.M. \& Lammie P. Immunopathology of granuloma formation and fibrosis in schistosomiasis. Parasitology Today, 1986, 2, 296-302.

RAGHeB S. \& Boros D.L. Characterization of granuloma T lymphocyte function from Schistosoma mansoni-infected mice. Immunology, 1989, 142, 3239-3246.

Rihet P., Demeure C., Bourgois A., Prata A. \& Dessein A.J. Evidence for an association between human resistance to Schistosoma mansoni and high anti-larval IgE levels. European Journal of Immunology, 1991, 21, 2679-2686.

Roberts M., Butterworth A.E., Kimani G., Kamau I., FulFord A.J.C., Dunne D.W., Ouma J.H. \& Sturrock R.F. Immunity after treatment of human schistosomiasis: Association between cellular responses and resistance to reinfection. Infection and Immunity, 1993, 61, 4984.

Schild H., Deres K., Wiesmüller K.H., Jung G. \& RemMENSEE H.G. Efficiency of peptides and lipopeptides of in vivo priming of virus specific cytotoxic T cells. European Journal of Immunology, 1991, 21, 2649-2654.

Sette A., Buus S., Colon S., Smith J., Miles C. \& Grey H. Structural characteristics of an antigen required for its interaction with Ia and recognition by T cells. Nature, 1987, 328, 395.
Sher A., Heiny S., James S.L. \& Asofsky R. Mechanisms of protective immunity against Schistotoma mansoni infection in mice vaccinated with irradiated cercariae. Journal of Immunology, 1982, 128, 1880-1886.

SMITHERS S.R. \& TerRy R.J. The infection of laboratory hosts with cercariae of Schistotoma mansoni and the recovery of adult worms. Parasitology, 1965, 55, 695-706.

Suttles J., Schwarting G.A. \& Stout R.D. Flow cytometric analysis reveals the presence of asialo-GM1 on the surface membrane of alloimmune cytotoxic T lymphocytes. Journal of Immunology, 1986, 136, 1586-1591.

Taylor M.G., Vidal A., Torpier G., Meyer D.J., Roitsch C., Balloul K.M., Southan C. Sondermeyer P., Premble S., LecocQ J.P., Capron A. \& Ketterer B. The glutathione transferase activity and tissue distribution of a clone MG $28 \mathrm{~K}$ protective antigen of Schistosoma mansoni. The European Molecular and Biological Journal, 1988, 7, 465-472.

TAYlor M.G. \& BICKLE Q.D. Toward a schistosomiasis vaccine: irradiated schistosome vaccines. Parasitology Today, 1986, 2, 132-134.

Wolowczuk I., Auriault C., Gras-Masse H., Vendeville C., Balloul J.M., Tartar A. \& Capron A. Protective immunity in mice vaccinated with the Schistosoma mansoni P28-I antigen. Journal of Immunology, 1989, 142, 1342-1350.

Wolowczuk I., Auriault C., Bossus M., Boulanger D., GrasMasse H., Mazingue C., Pierce R.J., Grezel D., Reid G.D., TARTAR A. \& Capron A. Antigenicity and immunogenicity of a multiple peptidic construction of the Schistosoma mansoni Sm28GST antigen in rat, mouse and monkey. Journal of Immunology, 1991, 146, 1987-1995.

Wolowczuk I., Auriault C., Gras-Masse H., Vendeville C., Balloul J.M., Tartar A. \& Capron A. Protective immunity in mice vaccinated with the Schistosoma mansoni P-28-1 antigen. Journal of Immunology, 1989, 142, 1342-1350.

Wolowczuk I., Delacre M., Roye O., Giannini S. \& Auriault C. Early production of interleukin 7 (IL7) in skin of Schistosoma mansoni infected mice leads to a clinical aggravation of the disease, associated with a decrease in production of gamma-interferon and IL12 (submitted).

Wolowczuk I., Kimani G., Boulanger D., Butterworth A.E., Gras-Masse H., Tartar A., Ouma J.H., Tarara R., Reid G.D., Koech D., Auriault C. \& Capron A. A study of human and primate lymphocyte responses to synthetic peptides of the Sm28GST protective antigen of Schistosoma mansoni (submitted).

Wu C.B., Verwaerde C., Gras-Masse H., Fontaine J., Bossus M., Tgrottein F., Wolowczuk I., Tartar A. \& Capron A. Schistosoma mansoni 28-kDa glutathione S-transferase and immunity against parasite fecundity and egg viability. Journal of Immunology, 1993, 150, 940-949.

Wyler D.J., Ehrlich H.P., Postlethwaite A.E., Raghow R. \& Murphy M.M. Fibroblast stimulation in schistosomiasis. VII Egg granulomas secrete factors that stimulate collagen and fibronectin synthesis. Journal of Immunology, 1987, 1138, 1581-1586. 